\title{
EMLÉKEIM A GYŐRI FELSŐFOKÚ TANÍTÓKÉPZŐ KEZDETI ÉVEIBŐL
}

\author{
BARSI ERNŐ \\ a Nyugat-Magyarországi Egyetem Apáczai Csere János Karának \\ ny. föiskolai tanára
}

Már 12 esztendeje tanítottam hegedủt, zenetörténetet, módszertant a győri Állami Zenekonzervatóriumban, miközben élő zenei bemutatókkal illusztrált ismeretterjesztő előadásokat tartottam nemcsak a városban, hanem vidéken, sőt pedagógus továbbképzéseken is, mikor a felsőfokúvá átszervezett győri tanítóképzőbe meghívtak vezetö-tanárnak. Nem volt könnyü megválni a zenekonzervatóriumi munkámtól, otthagyni kitünő hegedüs tanítványaimat, akikkel már közös hangversenyeken is szerepelhettem. De volt egy élményem, mely arra készítetett, hogy ezt a lépést megtegyem.

1957 nyarán a sárospataki múzeum felkérésére népdalt gyüjtöttem a bodrogparti falvakban, ahol szép, értékes népdalokat találtam. Sárazsadányban is több jó énekes dalait sikerült magnetofonra felvennem. Mellesleg akkor még olyan magnetofonja volt a múzeumnak, mely 23 kilogrammot nyomott, sőt attól félve, hogy annak a vidéki utakon még valami baja is eshet, egy faládában tartották szállítás közben. Így „mindössze” 40 kilogramm volt a súlya. A láda tetején volt egy fogantyú, azon átdugtunk egy rudat, annak két végét, egy segítség közremüködésével megfogtuk, s úgy vittük egyik helyről a másikra. Természetesen nem vittük házrólházra az énekes adatközlők lakására, hanem rendszerint az iskolában helyeztük el, s ide hívtuk az énekeseket.

Mikor a sárazsadányi énekesek már sok-sok szép népdalt ráénekelték a magnetofonra, kimentem velük az udvarra és sorra fényképeztem őket. Ahogy fényképezek, odapenderedik egy 9 éves kislány, s azt kérdi tőlem:

- Engem nem tetszik lefényképezni?

- Ha tudsz szépen énekelni, tégedet is lefényképezlek - feleltem.

- Tudok ám én énekelni - válaszolt a kislány.

- Akkor gyere be ide az iskolába, énekelj nekem, s én azt még fel is veszem magnetofonra.

Bementünk. Bekapcsoltam a magnetofont. S akkor ez a kislány oly szépen énekelte el Szedri báró balladáját, hogy én ilyen éneklést gyermektől még soha nem hallottam. 
Valósággal szíven ütött ez a gyermektől hallott csodálatos éneklés. Mindjárt arra gondoltam, hogy ezt a gyermeket kellene zenére tanítani, s nem olyan városi gyerekeket, akiket csak szüleik kényszerítenek arra, hogy zenét tanuljanak. Ímmelámmal talán gyakorolgatnak is, de mihelyt tehetik, abba is hagyják a muzsikálást. Vagy ha közülük akad valaki, aki zenei pályára téved, a zenét nem megszerettetni, hanem megutáltatni fogja tanítványaival. De hát hol tanulhatna zenét ez a kis Szabó Katalin? Akkor meg a közeli Sárospatakon nem volt zeneiskola, csak a távoli Miskolcon. Ha a zsadányi iskola tantestületében lett volna valaki, aki zeneileg is képzett, elindíthatta volna a zenei pályába vezető úton. De bizony ott ilyen tanító nem volt. Arra is gondoltam, hogy el kellene hoznom Győrbe tanulni. Leveleztünk is. A kis Kati olyan vágyakozva írta nekem: „Én úgy szeretnék zeneiskolába járni!” De ehhez bizony Győrött lakás, teljes ellátás kellett volna. Kollégiumi elhelyezése nem lehetett, mivel az akkori törvények szerint más megyéből való ilyet nem kaphat. Magunkhoz is vettem volna ezt a rendkívül tehetséges kislányt. Ám ekkor még nem volt Győrben lakásunk. Egyik albérletből költözködtünk a másikba, hét év alatt összesen nyolcszor. Így hát ez a lehetöség is elesett. Aztán abbamaradt minden. A rendkívül tehetséges Szabó Kati elkallódott a magyar zenei élet számára.

Azzal tisztában voltam, hogy a Felsőfokú Tanítóképzőben nem lesznek olyan kitűnő hangszeres tanítványaim, mint amilyenek a konzervatóriumban voltak. De tudtam, hogy akiket itt tanítani fogok, elsősorban falura fognak kerülni, és elindíthatnak a zenei pályán sok tehetséges gyereket, akik a városi zeneiskolától távol soha nem kaphattak volna zenei képzést, s így elvesztek volna a zene számára.

A Felsőfokú Tanítóképzőben kezdetben meglepően jó lehetőségei adódtak a hallgatók zenei képzésének. Minden hallgatónak kötelező volt a hangszertanulás, egyéni foglalkozással heti két órában. Ezen kívül csoportos ének-zeneelméleti, zenetörténeti óra volt ugyancsak heti két órában. Karének, a hangszerjátékban magasabb fokon lévőknek zenekari gyakorlat heti két órában. Második évben ehhez még hozzájött az énektanítás módszertana, ugyancsak heti két órában. A jelentkezők már ebből úgy gondolták, hogy a felvételhez komoly zenei felkészültség szükséges. Így az 1959-ben az első tanévre felvett 60 hallgatóból vonószenekart tudtam szervezni. Sőt még vonósnégyest is alakítottam 3 hallgató meg saját magam részvételével. Ennek próbáit akkor még a délelötti órarendbe is be tudtam állítani. Olyan vonószenekarom volt, hogy pl. a Szabolcsi Bence által felfedezett Vivaldi: Il Ritiro címet viselö hegedüversenyét is be tudtam velük mutatni. Magam játszottam a szólóhegedű szólamot, $\mathrm{s}$ a zenekar dirigálás nélkül tudott kísérni.

A hegedűseim között természetesen kezdők is voltak. Ám hegedűmetodikai ismeretek birtokában még ezekkel is el tudtam érni, hogy hegedü-duókat muzsikáljunk együtt. Kissé tréfásan azt szoktam mondani, hogy ha egy kezdő hegedüst jól állítanak be a hangszerén, akkor az nem is tud hamisan, csak tisztán játszani. Ám egy-egy hegedüs hallgatóm olykor azt is bizonyította, hogy lehet azért a hegedün hamis hangot is fogni. Bár az is előfordult, hogy az egyik elég bizonytalanul éneklö 
fiú a hegedűjátékban annyira vitte, hogy amikor kikerült tanítónak, hegedűje segítségével tudott éneket tanítani.

Énekóráimon igyekeztem játékos módon vezetni be a hallgatóimat a kottaírásolvasás elsajátításába. Ezzel a módszerrel aztán tanítóként is szép eredményt tudtak elérni tanítványaim.

$\mathrm{Az}$ is sokat jelentett, hogy a zeneirodalmat hangszerem segítségével élö zeneként tudtam illusztrálni. Arra is lehetőségem volt, hogy magam is hangversenyeket adjak olykor neves müvészek közremüködésével. Már az első év őszén pl. szonáta estet tudtam adni olyan európai hírü zongoraművésszel, mint Kósa György, aki zongorából Bartók Béla, zeneszerzésböl pedig Kodály Zoltán növendéke volt, és mint a budapesti Liszt Ferenc Zenemüvészeti Föiskola tanára jött el Györbe velem muzsikálni.

Tanítványaimmal is többször elmentünk egy-egy faluba zenés estet adni. Még az is előfordult, hogy erre egy gondatlanságból származó károkozás adott alkalmat. Mivel hangszertárunknak is én voltam a felelőse, a fiúk tőlem kérték el a nagybögőt egy általuk rendezett „,bulira”. Hogy-hogy nem, a nagybőgőnek betörték az oldalát. Mit csinálhat ilyenkor egy hangszerért felelős tanár? Leszidja a károkozókat, utasítja öket, hogy csináltassák meg, esetleg azt is hozzáteszi, hogy többet nem fogják megkapni.

Én más módszerhez folyamodtam. Azt mondtam, hogy meg fogunk tanulni egy kórusszámokból, meg hangszeres darabokból összeállított müsort, s azzal elmegyünk valamelyik faluba hangversenyt adni. Annak bevételéből talán meg tudjuk csináltatni a nagybőgöt. Így is történt. Természetesen nem az énekórákon, hanem ezeken kívül összejöttek a hallgatóim a müsorszámokat tanulni. El is készültünk szépen, és egy Győrhöz közeli faluban megrendeztük a „Bőgö-koncertet”. Nem csak bevételt, de igen szép sikert is hozott a hangverseny. S az én tanítványaim gazdagabbak leettek sok szép zenemü elsajátításával. Az est után olyan boldogok voltak, hogy még hazafelé indulva az utcán és a buszmegállóban is énekelték a szép kórusszámokat.

Kitünő lehetőséget kaptam itt a Felsőfokú Tanítóképzőben a néprajzi munkára is. Mielött ide kerültem, már a Sályi pásztorok címü néprajzi pályamunkám országos 3. díjat kapott. Mikor a budapesti Néprajzi Múzeum osztályvezetöje, az Önkéntes Néprajzi Gyüjtőmozgalom szervezője, Dr. Morvay Péter megtudta, hogy a tanítóképzőbe kerülök, azonnal leutazott Győrbe, és azt mondta: „Neked itt néprajzi szakkört kell vezetni”. Azt is elintézte, hogy a képző vezetősége ezt a munkát engedélyezze.

A szakköri munka el is indult. Azok a hallgatók, akiknek az énekórákat tartottam, vagy hegedülni tanítottam, kivétel nélkül jelentkeztek is a néprajzi szakkörbe. Nemcsak foglalkozásokat tartottam nekik, hanem kijártam velük a falvakba gyüjteni. Mivel az én tanítványaim különböző érdeklődésủek voltak, különböző képességekkel is rendelkeztek, a gyüjtendő anyag témáit igyekeztem hozzájuk igazítani. Ez 
azért is jó volt, mert a népzenén kívül a néprajz sok ágával kellett nekem is foglalkozni. Így tanítva-tanultam magam is a néprajzot, aminek azután igen sok hasznát vettem. Így értettem meg pl. népdalszövegeinkben, sőt költőink verseiben is sok olyan kifejezést, fogalmat, melyet csak a régi falusi élet ismeretében lehet megérteni. Hogy csak egy példát mondjak: Ady Endrének ilyen verssora is van, „A vér rakonca csuda szép". Mit ért ebböl pl. egy mai gyerek? Természetesen egy-egy elnevezés az ország különböző tájain nem ugyanazt jelentheti. A rakoncát most abban az értelemben próbáljuk megérteni, ahogyan $A d y$ gondolta. Egyes vidékeken rakoncának nevezik a parasztszekér első tengelyére erősített két pöcköt. Mikor fordul a szekér, annak rúdja nekiütközik a pöcöknek, s a rúd nem 180 fokos fordulatot tesz, hanem a pöcöknél megáll, s így balra vagy jobbra engedi fordulni a szekeret. Vagyis a rakonca teszi azt irányíthatóvá. Használjuk ezt többféle értelemben is. Például a „rakoncátlan gyerek” kifejezésben. Értsük ezen azt, hogy az ilyen gyereknek nincs rakoncája, tehát irányíthatatlan. S Adynál a vér-rakonca arra utal, hogy a vérünk, vérmérsékletünk néha olyan dolgokat csináltat velünk, amit egyébként nem tennénk.

A gyüjtött anyagból hallgatóim szép pályamunkákat készítettek, s az országos néprajzi, honismereti pályázatokon, meg az Országos Tudományos Diákköri Konferenciákon egyre jobb eredménnyel szerepeltek. Később azt is elérték, hogy néprajzi témából is lehessen szakdolgozatot írni. Szinte egy könyvtárat is betöltő hatalmas anyagot gyüjtöttek, írtak már tanítványaim, s nem egy közülük nyomtatásban is megjelent.

Közben természetesen magam is egyre szélesebb területen végeztem néprajzi gyüjtést, írtam a pályamunkákat. S egy „nagydíjas” pályamunkámat: A zene egy sályi pásztor életében címüt doktori disszertációként is elfogadták az Eötvös Loránd Tudományegyetemen.

„Néprajzos tanítványaim” nemcsak a szellemi néprajz területéhez tartozó anyagot gyüjtöttek, hanem tárgyakat is gyüjtöttek. Ebből már az első év végén, $\mathrm{s}$ természetesen azután is kiállítást rendeztünk. Egyik fiú Nyúl községben egy faekére bukkant. Mindjárt arra gondolt, hogy kiállításunkat mennyivel érdekesebbé, vonzóbbá tenné. Gazdájától meg is szerezte. Most már csak az volt a problémája, hogy hogyan tudja azt Győrbe behozni? Gondolt egy nagyot és merészet: volt egy motorbiciklije, s elhatározta, hogy utána köti a faekét és bevontatja a kiállításunk helyszínére. Meg is tette. A kiállítást látogatók meg is csodálták. Köztük újságíró is volt, és mint ritka érdekességet, a faeke motorbiciklis bevontatását meg is írta Kisalföld címü újságban. Mikor ezt az én kedves tanítványom elolvasta, nagyon megijedt. Mindjárt arra gondolt, hogy ha ezt a rendörök is elolvassák, őt meg fogják büntetni. Szerencsére a rendőrök nem olvastak újságot, s így a büntetés elmaradt.

A néprajzi kiállítások megnyitása mindig ünnepélyesen, szép müsorral történt, melyre tanítványaim adatközlőjüket, a néprajzi tárgyak ajándékozóit is meghívták. A népdalokból feldolgozások is készültek erre az alkalomra. A megnyitón az ilyen 
dalokat először az adatközlöjük énekelte el, s utána következett annak feldolgozása. Mikor egyik alkalommal egy egyházaskeszői énekes, aki mellesleg gyüjtőjének nagyapja is volt, meghallotta szép, régi stílusú dalát a hallgatók énekkarának elöadásában, melyet a vonószenekar is kísért, bizony kihulltak a könnyei.

A kiállításokat sokan meg is nézték. Még általános iskolás tanulókat is elhoztak megtekintésére.

Visszaemlékezve sárospataki diákéveimre, elevenen élt bennem tanáraink „Péntek esték” címet viselő előadássorozata, amelyet nemcsak a diákoknak, hanem a város közönségének is tartottak. Rendkívüli élményt jelentettek számunkra ezek az előadások. Elmondtam ezt a kollégáimnak, s elhatároztuk, hogy mi is fogunk ilyen elöadásokat tartani a városi közönség bevonásával. Így indítottuk el a „Kedd esték" sorozatot, amelyen oktatóink irodalmi, zenetörténeti, képzőmüvészeti elöadásokat tartottak, s ezeken a lehetőség szerint még a hallgatóink is közremüködtek zeneszámokkal, szavalatokkal. Jöttek is ezekre a „Kedd esték”-re sokan a városból. Így vált Felsőfokú Tanítóképzőnk Győr egyik kulturális központjává. Ezekből az előadásokból, meg oktatóink tudományos munkáiból, tanulmányaiból kötet született meg Embernevelés címmel.

Mikor 1959-ben átjöttem a Felsőfokú Tanítóképzőbe, nem is álmodtam, hogy 50 esztendő múlva, mint óraadó még nyugdíjasként is részt vehetek munkájában. Ha számba veszem, hogy ez alatt az idő alatt ötezernél is több előadást tarthattam nemcsak itt, hanem országszerte, sőt határainkon túl, Kaukázustól a szomszédos országokon, Németországon, Svájcon át Kanadáig. Megjelent köteteim száma negyvenet meghaladja. Folyóiratokban, különböző múzeumi évkönyvekben, még határainkon kívül kiadott kötetekben közölt írásaim több százra tehetők. Úgy érzem, hogy mindezt csak úgy tudtam elérni, hogy ötven évvel ezelött átjöttem a Felsőfokú Tanítóképzőbe. Ha voltak is közben nehézségek, mégis itt tudtam eredményesen dolgozni, tanítványok sorában is elültetni a gyermekek, a tudás, az alkotómunka szeretetét magyar hazánk javára. Szívből kívánom kedves kollégáimnak, hogy legyen erejük, jó egészségük szép munkájuk végzéséhez, s találjanak benne sok-sok örömet. 